\title{
Interleukin-6 and Glucocorticoids Synergistically Induce Human Immunodeficiency Virus Type-1 Expression in Chronically Infected U1 Cells by a Long Terminal Repeat Independent Post-Transcriptional Mechanism
}

\author{
Audrey L. Kinter, ${ }^{1 *}$ Priscilla Biswas, ${ }^{2 *}$ Massimo Alfano, ${ }^{3}$ Jesse S. Justement, ${ }^{1}$ Barbara Mantelli, ${ }^{2}$ \\ Chiara Rizzi, ${ }^{3}$ Alessandra R. Gatti, ${ }^{3}$ Elisa Vicenzi, ${ }^{3}$ Peter Bressler, $^{4}{ }^{\wedge}$ and Guido Poli $^{3}$ \\ ${ }^{1}$ Laboratory of Immunoregulation, National Institute of Allergy and Infectious Diseases, National Institutes \\ of Health, Bethesda, MD, USA \\ ${ }^{2}$ Laboratory of Clinical Immunology, San Luigi AIDS Center, San Raffaele Scientific Institute, Milano, Italy \\ ${ }^{3}$ AIDS Immunopathogenesis Unit, San Raffaele Scientific Institute, Milano, Italy \\ ${ }^{4}$ Duke University Medical Center, Durham, NC, USA
}

Accepted August 9, 2001

\begin{abstract}
Background: Glucocorticoids (GC) such as dexamethasone (Dex) can directly upregulate human immunodeficiency virus type-1 (HIV-1) replication in acutely infected cells and potentiate HIV expression from chronically infected promonocytic Ul cells stimulated with tumor necrosis factor- $\alpha$ (TNF- $\alpha)$. We have here investigated the potential effect of Dex in Ul cells stimulated with interleukin-6 (IL-6), a cytokine inducing virus expression by acting mostly at a post-transcriptional level on the virus life cycle.

Materials and Methods: Virus production in culture supernatants was evaluated by reverse transcriptase (RT) activity. GC receptor expression was tested by both binding of $\left[{ }^{3} \mathrm{H}\right]$-Dexamethasone 21-mesylate and Northern blotting. Cell-associated HIV protein expression was analyzed by Western blotting, whereas both HIV and monocyte chemoattractant protein-1 (MCP-1) RNA accumulation were evaluated by Northern blotting. HIV transcription was tested by long terminal repeat (LTR) chloramphenicol acetyl transferase (CAT) assay after transient transfection of U1 or U937 cells. Formation of activating protein-1 (AP-1) DNA binding complex in nuclear cell extracts was visualized by electrophoretic mobility shift assay (EMSA), whereas ERK1/2 mitogen-activated
\end{abstract}

protein kinase (MAPK) phosporylation was studied by Western blotting.

Results: IL-6 and Dex synergistically induced HIV expression in U1 cells, and this effect was blocked by RU 486. No substantial HIV RNA accumulation was demonstrated in U1 cells co-stimulated with IL-6 and Dex, whereas IL-6 upregulated the expression of MCP-1 RNA, and this effect was inhibited by Dex. In contrast, Dex potentiated IL-6 induced activation of AP- 1 and ERK $1 / 2$ MAPK phosphorylation, as revealed by EMSA. HIV-1 LTR driven transcription was observed in Ul cells stimulated with TNF- $\alpha$ and this effect was potentiated by Dex. In sharp contrast, no induction of LTR-directed CAT activity was observed in transfected Ul cells (or in their parental uninfected U937 cells) stimulated with IL-6 and Dex either alone or in combination.

Conclusions: High levels of virion production can be induced in latently infected cells by stimulation with IL-6 and Dex in the absence of activation of the HIV LTR or viral transcription in spite of activation of both ERK1/2 MAPK and AP-1. These findings suggest the existence of LTR-independent pathways influenced by cytokine and GC through which HIV can maintain substantial levels of protein expression and virion production.
Address correspondence and reprint requests to: Guido Poli, P2-P3 Laboratories, DIBIT, Via Olgettina n. 58, 20132, Milano, Italy. Phone: (39)-02-2643-4909; fax: (39) 02-2643-4905; e-mail: poli.guido@hsr.it.

*ALK and PB equally contributed to this study. ^ Current address: Carolina Allergy and Asthma Consultants, Cary, NC.

\section{Introduction}

The capacity of the human immunodeficiency virus type-1 (HIV-1) to replicate in immune cells, mostly $\mathrm{CD}^{+} \mathrm{T}$ lymphocytes and mononuclear phagocytes, is a major determinant of disease progression (1). Various host factors have been found to modulate viral 
replication in vitro, including several cytokines and glucocorticoid hormones (GC) that have been previously described as important determinants. In particular, pro-inflammatory cytokines such as tumor necrosis factor- $\alpha$ (TNF- $\alpha$ ), interleukin- $1 \beta$ (IL- $1 \beta$ ), interferon- $\gamma$, and IL- 6 have been shown to upregulate HIV replication in a variety of in vitro model systems. Conversely, anti-inflammatory cytokines including IL-4, IL-10 and transforming growth factor- $\beta$ can either suppress or activate virus expression as a function of the experimental conditions, as reviewed $(1,2)$.

GC are important mediators of the hypothalamuspituitary-adrenal (HPA) axis that is activated as a feedback system in response to inflammation (3). The involvement of the HPA axis in HIV disease has been associated with either increased or decreased levels of cortisol, particularly after combination therapy including protease inhibitors (4-8). In vitro, GC have been reported to induce HIV replication. Early studies indicated that addition of high concentrations of hydrocortisone to co-cultures of peripheral blood mononuclear cells (PBMC) of infected individuals with mitogen-stimulated allogeneic PBMC increased the frequency of virus isolation and/or induced higher levels of virus production compared to GCuntreated co-cultures $(9,10)$. A putative GC responsive element was early identified in the HIV-1 long terminal repeats (LTR) (11-14) and evidence of upregulation of virus production have been obtained in both chronically infected cell lines $(15,16)$ and monocyte-derived macrophages $(17,18)$.

Although GC are classic anti-inflammatory agents that suppress the synthesis and release of proinflammatory cytokines and chemokines (19-25) synergistic effects between GC and certain cytokines, including IL-6, have been observed (26-31). In this regard, we have reported that treatment of chronically infected Ul cells with physiologic concentrations $\left(10^{-8} \mathrm{M}\right)$ of GC alone did not induce virus production, but strongly potentiated the induction of HIV expression by TNF- $\alpha$ (32), a cytokine which stimulates HIV transcription driven by the activation of the cellular transcription factor NF-kB that binds to its long terminal repeats (LTR) (33). The present study investigated the effect of GC on HIV expression induced by IL-6, a cytokine that upregulates HIV expression from U1 cells by acting mostly at a post-transcriptional level (34).

\section{Materials and Methods}

\section{U1 Cell Line and Reagents}

The Ul cell line was derived from U937 promonocytic cells surviving the cytopathic effect associated with the acute infection by HIV-1LAI/IIIB $(35,36)$. Ul cells contain two integrated copies of proviral HIV DNA and are characterized by low constitutive levels of virus expression that can be upregulated by several cytokines and phorbol esters $(37,38)$. Ul cells $\left(2 \times 10^{5}\right.$ cells $\left./ \mathrm{ml}\right)$ were resuspended in RPMI 1640
(M.A. Whittaker Bioproducts, Walkersville, MD) supplemented with $1 \mathrm{mM}$ HEPES buffer, antibiotics and glutamine plus $10 \%$ fetal calf serum (FCS) (Hyclone Laboratories, Logan, UT), containing less than $7 \mathrm{pg} / \mathrm{ml}$ of endotoxin. The cells were cultured in 96 or 48 well flat-bottomed plastic plates (Costar, Cambridge, MA) and incubated with the different stimuli at $37^{\circ} \mathrm{C}$ in $5 \% \mathrm{CO}_{2}$. Mifepristone (RU 486), a pharmacological compound blocking the binding of GC and progesterone to their cytoplasmic receptors (39), was kindly provided by Dr. Stoney Simons, National Institutes of Health, Bethesda. Ul cells were stimulated with TNF- $\alpha$ (100 U/ml; Genzyme Corp., Boston, MA), IL-6 (100 U/ml; R \& D Systems), Dexamethasone (Dex) $\left(10^{-8} \mathrm{M}\right.$; Sigma Chemical Corp., St. Louis, MS), alone or in combination, in the presence or absence of RU $486\left(10^{-6} \mathrm{M}\right)$.

\section{Glucocorticoid Receptor Binding Assay}

Cytosol was prepared by washing $2 \times 10^{7} \mathrm{Ul}$ cells 3 times in PBS and by freezing the cell pellet on dry ice. All reactions from this point on were performed at $4^{\circ} \mathrm{C}$. Receptor binding was assayed as described (40) with minor modifications. The pellets were thawed by adding $400 \mu \mathrm{l}$ of binding buffer $(25 \mathrm{mM}$ HEPES, pH: 7.8, $20 \mathrm{mM} \mathrm{Na} \mathrm{MoO}_{4}, 1 \mathrm{mM}$ EDTA, $10 \%$ glycerol). The suspension was vortexed, mixed, and cellular debris was removed by centrifugation in a microfuge (Eppendorf, Hamburg, Germany). An aliquot $(95 \mu \mathrm{l})$ of cytosol was labeled with $\left[{ }^{3} \mathrm{H}\right]-\mathrm{Dex}$ 21-mesylate (37 Ci/mmole, New England Nuclear, Wilmington, DE) in the presence or absence of an excess of $\left[{ }^{1} \mathrm{H}\right]$-Dex. In order to remove the unbound steroid, a $10 \%$ solution of dextran-coated charcoal suspension was added. The precipitate was centrifuged and the number of bound receptors was determined by counting aliquots of the supernatants on a scintillation counter.

\section{Reverse Transcriptase (RT) Activity Assay}

Thirty $\mu \mathrm{l}$ of culture supernatants were collected at the indicated days after stimulation of Ul cells and were stored at $-80^{\circ} \mathrm{C}$ until tested for the presence of RT activity, as previously described $(32,34)$. Briefly, $5 \mu \mathrm{l}$ of Ul supernatants were added, in duplicate, to $25 \mu \mathrm{l}$ of a mixture containing poly (A), oligo (dT) (Pharmacia, Piscataway, $\mathrm{NJ}), \mathrm{MgCl}_{2}$ and $\left[{ }^{32} \mathrm{P}\right]-$ labeled deoxythymidine 5'-triphosphate (dTTP) (Amersham, Arlington Heights, IL) and incubated for $2 \mathrm{~h}$ at $37^{\circ} \mathrm{C}$. Then, six $\mu \mathrm{l}$ of the mixture were spotted onto DE81 paper (Whatman International, Maidstone, UK), air-dried, washed five times in $2 \times$ standard saline citrate buffer, and two additional times in $95 \%$ ethanol. The paper was then dried, cut, and counted in a Beckman LS 5000 scintillation counter.

\section{Western Blot of Cell-associated HIV Proteins}

Twenty $\mu$ l from the lysate of $10^{7}$ cells were added to each lane and subjected to electrophoresis through 
10-20\% gradient polyacrylamide gels (Integration Separation Sci., Hyde Park, MA) for $6 \mathrm{~h}$. The migrated proteins were then transferred overnight onto nitrocellulose filters. After saturation with a 5\% milk solution, filters were incubated for $2 \mathrm{~h}$ with $1: 1,000$ (vol/vol) dilution of an AIDS patient serum containing high titers of anti-HIV antibodies (Ab) recognizing most viral proteins (32). Filters were then washed and incubated for 90 min with $\left[{ }^{125} \mathrm{I}\right]-$ labeled protein A $(200,000 \mathrm{dpm} / \mathrm{ml})$, washed again, air-dried, and exposed overnight to $\mathrm{X}$-ray film.

\section{Northern Blot for HIV-1 and Monocyte Chemoattractant Protein-1 (MCP-1) RNAs}

Ul cells were either left unstimulated or were stimulated with TNF- $\alpha$ or IL- 6 in the presence or absence of Dex for 48 or $5 \mathrm{~h}$ for HIV-1 and MCP-1, respectively. RNA extraction was performed using an RNA isolation kit (Stratagene, La Jolla, CA). Northern blot analysis was performed as previously described $(32,34)$. Briefly, $10 \mu \mathrm{g}$ of each sample was electrophoresed through a $0.8 \%$ formaldehyde agarose gel. The RNA was transferred to nitrocellulose by Northern blotting and filters were hybridized with an $\left[\alpha{ }^{32} \mathrm{P}\right]$-labeled homologous HIV LTR probe (Sst I-BssHII) and then stripped and re-hybridized with a labeled $\left[\alpha-{ }^{32} \mathrm{P}\right]$-labeled- $\beta$-actin probe. For MCP-1 RNA detection human MCP-1 cDNA (0.672 Kb PstlPstl fragment) (41) was labeled by the "ready to go" DNA labeling system (Pharmacia Upjohn) with $\left[\alpha^{32} \mathrm{P}\right]-$ dCTP $(3,000 \mathrm{Ci} / \mathrm{mmol}$, Amersham). The human glucocorticoid receptor cDNA probe was kindly provided by Dr. Ronald Evans (The Salk Institute for Biological Studies, La Jolla, CA), whereas the human IL-6 receptor cDNA probe was kindly provided by Dr. Tadamitsu Kishimoto (Osaka University, Osaka, Japan).

Electrophoretic Mobility Shift Assay (EMSA)

for Activating Protein-1 (AP-1)

AP- 1 analysis was performed on nuclear cell extracts prepared from $5 \times 10^{6}$ of pelletted Ul cells, resuspended and lysed on ice in $25 \mu \mathrm{l}$ of buffer A containing $0.2 \%$ of NP-40 for $10 \mathrm{~min}$ and vortexed for 10 seconds. Buffer A (10mM HEPES pH 7.9, $10 \mathrm{mM} \mathrm{KCl}, 0.1 \mathrm{mM}$ EDTA, $0.1 \mathrm{mM}$ EGTA, $1 \mathrm{mM}$ DTT) was supplemented with the following protease inhibitors: leuptin $(10 \mu \mathrm{g} / \mathrm{mL})$, pepstatin A $(10 \mu \mathrm{g} / \mathrm{mL})$, aprotinin $(33 \mu \mathrm{g} / \mathrm{mL}), \mathrm{E}-64(10 \mu \mathrm{g} / \mathrm{mL})$, AEBSF (1 mmol/L), diisopropyl fluorophospate (DFP) ( $3 \mathrm{mmol} / \mathrm{L})$, and with the following phosphatase inhibitors: sodium vanadate $\left(\mathrm{Na}_{3} \mathrm{VO}_{4}\right)$ ( $1 \mathrm{~mol} / \mathrm{L})$, sodium fluoride $(\mathrm{NaF})(50 \mathrm{mmol} / \mathrm{L})$. After centrifugation, the supernatant was removed and the pelleted nuclei were resuspended in $20 \mu \mathrm{l}$ of cold buffer C (20 mM HEPES, pH 8.0; 25\% glycerol; $0.42 \mathrm{M}$ $\mathrm{NaCl} ; 1.5 \mathrm{mM} \mathrm{MgCl} 2 ; 0.2 \mathrm{mM}$ EDTA; $0.5 \mathrm{mM}$ DTT, plus the above listed protease and phosphatase inhibitors) for 15 min on ice. After centrifugation, supernatant was collected, analyzed for protein concentration and tested for EMSA. Equal amounts of nuclear cell extracts $(2 \mu \mathrm{g})$ were added to a reaction mixture composed of binding buffer (20 mM HEPES, pH 8.0; $20 \%$ glycerol; $100 \mathrm{mM} \mathrm{KCl} ; 0.6 \mathrm{mM}$ EDTA; $5 \mathrm{mM}$ DTT; $100 \mathrm{mM} \mathrm{KCl}, 1 \mathrm{mM} \mathrm{MgCl}_{2}, 0.3 \mathrm{mM}$ PMSF, $4 \mu \mathrm{g} \mathrm{BSA}), 1 \mu \mathrm{l}$ of poly(dI:dC, $5 \mathrm{mg} / \mathrm{ml}$ ) (Pharmacia Upjohn) and $5 \times 10^{4} \mathrm{cpm}$ of labeled AP-1 probe: 5'-CGC TTG ATG AGT CAG CCG GAA-3', 3'-GCG AAC TAC TCA GTC GGC CTT-5' (Promega, Madison, WI) labeled with $\left[{ }^{32} \mathrm{P}\right]$-ATP (Amersham) using polynucleotide kinase T4 (New England Biolabs, Beverly, MA) in a final volume of $15 \mu \mathrm{l}$ and incubated for $30 \mathrm{~min}$ at room temperature $\left(\mathrm{rt}^{\circ}\right)$. For supershifting experiments, parallel aliquots of nuclear cell extracts were incubated in the presence or absence of $1 \mu \mathrm{g}$ of Ab (Santa Cruz Biotecnology, Inc., Santa Cruz, CA) directed to different components of AP-1 for $30 \mathrm{~min}$ at $\mathrm{rt}^{\circ}$. One $\mu \mathrm{l}$ of $\left[^{32} \mathrm{P}\right]$-ATP-labeled doublestranded probe $(0.5 \mathrm{ng})$ was then added and the reaction was incubated at $\mathrm{rt}^{\circ}$ for $30 \mathrm{~min}$ and then run on a $5 \%$ acrylamide gel in $1 \times \operatorname{TBE}(0.0045 \mathrm{M}$ Tris-borate, $0.001 \mathrm{M}$ EDTA) for $4 \mathrm{~h}$ at $150 \mathrm{~V}$. Radioactive bands were revealed by autoradiography of dried gels.

\section{Western Blot Analysis of ERK1/2 Mitogen-activated Protein Kinases (MAPK)}

Ten $\mu \mathrm{l}$ of nuclear cell extracts were electrophoresed on a $10 \%$ SDS-PAGE and subsequently transferred to a nitrocellulose membrane (Hybond ECL, Amersham, Little Chalfont, UK) by electroblotting. Membranes were incubated with a blocking solution of $5 \%$ nonfat milk, $20 \mathrm{mM}$ Tris, $\mathrm{pH} 7.6,137 \mathrm{mM}$ $\mathrm{NaCl}, 0.2 \%$ Tween 20 , for $\mathrm{l} \mathrm{h}$ at $\mathrm{rt}^{\circ}$, and further incubated overnight at $4^{\circ} \mathrm{C}$ with monoclonal $\mathrm{Ab}$ $(\mathrm{mAb})$ recognizing phoshorylated-ERK, D-4 (Santa Cruz Biotechnology). mAb binding was visualized by using horseradish peroxidase-conjugated antimouse Abs (Amersham Pharmacia Biotech). The signal was revealed by the enhanced chemiluminescence system (ECL, Amersham) according to the manufacturer's instructions. For determination of the total amount of ERK 1/2, the filters were stripped and re-blotted using the anti-ERK2 mAb D-2 (Santa Cruz Biotechnology). Biotinylated protein markers were purchased from Cell Signaling Technology (Beverly, MA).

\section{LTR-Chloramphenicol Acetyl Transferase (CAT) Transient Transfections}

$10^{7} \mathrm{Ul}$ cells were transiently transfected with an HIV-1 LTR CAT construct (one $\mu \mathrm{g}$ of plasmid DNA per 5-10 $\times 10^{6}$ cells) by hypotonic DEAE dextran, as described (32). Four $h$ after transfection, cells were stimulated as indicated and protein extracts were prepared $36 \mathrm{~h}$ after transfection. Cell supernatants were harvested from the remainder of the culture $72 \mathrm{~h}$ after transfection and stored at $-80^{\circ} \mathrm{C}$ for determination of the RT activity content. For the 
generation of protein extracts, Ul cells were washed in phosphate-buffered saline (PBS), resuspended in $100 \mu \mathrm{l}$ of Tris ( $100 \mathrm{mM}, \mathrm{pH} 7.5)$ plus $0.1 \%$ Nonindet P-40 (NP-40), and disrupted by three cycles of freezing and thawing. The cell debris was pelleted and the protein concentration of the supernatant was measured with a protein assay kit (Bio-Rad, Richmond, CA). Each CAT assay was adjusted to contain equal amounts of protein from each individual transfection. Fold induction of CAT activity was calculated by dividing the counts per min (cpm) of the test samples by the cpm of the samples obtained from unstimulated cells. In some experiments, uninfected parental U937 cells (41) were transfected and stimulated by cytokines and/or Dex following the same procedure.

\section{Results}

Synergistic Induction of HIV Expression in U1 Cells by Stimulation with $I L-6$ and $G C$

The Ul cell line is a well-characterized model of inducible HIV-1 expression (38). Northern blot analysis indicated that Ul cells constitutively express $2 \mathrm{~Kb}$ mRNA in the absence of detectable levels of unspliced $9 \mathrm{~Kb}$ transcripts suggestive of a Revdependent latency (37). Subsequent studies have, however, linked the phenotype of restricted virus expression of Ul cells to a defective function of Tat rather than Rev (42-44).

Expression of the GC receptor in Ul cells was observed by Northern blot analysis using a cDNA probe for the human GC receptor (data not shown). In addition, receptor binding studies using $\left[{ }^{3} \mathrm{H}\right]$-Dex indicated that unstimulated $\mathrm{U} I$ cells express approximately 3,800 receptors per cell (Table 1 ), a number of molecules adequate to transduce biological effects (40). Stimulation of U I cells with Dex alone did not induce HIV expression from Ul cells, as measured by supernatant-associated RT activity, whereas IL-6 upregulated virus production (34). As observed with TNF- $\alpha$ (32) co-stimulation of U 1 cells with IL-6 and Dex resulted in a synergistic effect on virus production lasting for several days of culture (Figure 1A). The synergistic effect observed in U1 cells co-stimulated by cytokines and Dex was mediated by a functional intracellular receptor, as demon- strated by the ability of the receptor antagonist RU 486 (39) of suppressing the effect of GC on cytokinemediated HIV expression in these cells (Figure 1B). In addition to increase RT activity, Dex enhanced the accumulation of cell-associated HIV proteins induced by IL-6, as demonstrated by Western blot analysis (Figure 2 ).

The steroid potentiating effect was relatively specific in that virus expression following Ul cell stimulation with granulocyte-macrophage colony stimulating factor, another HIV-inductive cytokine $(35,45,46)$ was not further enhanced by Dex (data not shown). No toxicity or substantial changes in the levels of cell proliferation were observed in the different experimental conditions tested. No further increase of RT activity was seen when cells were stimulated with higher concentrations (up to $10^{-5} \mathrm{M}$ ) of Dex in the presence or absence of IL-6 (data not shown).

Since GC have been reported to upregulate IL- 6 receptor mRNA and cell surface expression in epithelial and epathoma cell lines $(27,47)$ we have investigated whether the observed synergy could be accounted for by a similar effect in Ul cells. Total RNA was isolated from Ul cells after 8 and $24 \mathrm{~h}$ of stimulation with IL-6, Dex or their combination, and probed for IL- 6 receptor. However, Dex did not increase the accumulation of IL-6 receptor message at either time point. Furthermore, IL-6 stimulation did not upregulate the number of GC receptors in $\mathrm{U} 1$ cells, as determined by Northern blot and/or binding studies (data not shown).

\section{Lack of Effect of IL-6 and Dex on Steady-state HIV RNA Accumulation}

The predominant effect of IL-6 in Ul cells is a posttranscriptional activation of HIV expression occurring without evident accumulation of viral transcripts, as determined by Northern blot analysis (34). Consistently with the lack of effect on both released RT activity and expression of cell-associated viral proteins, Ul cell stimulation with Dex alone did not increase the low constitutive levels of $2 \mathrm{~Kb}$ mRNA. IL-6 did not upregulate HIV transcripts either in the presence or absence of Dex (Figure 3A) whereas the steroid potentiated TNF- $\alpha$ mediated upregulation of viral RNA, as previously reported (32). Therefore, Dex-mediated

Table 1. Specific binding of GC in U1 cells

\begin{tabular}{cccc}
\hline Total Binding (cpm) & Nonspecific Binding (cpm) & Specific Binding (cpm) & Receptors Per Cell \\
\hline $1,081 \pm 28$ & $424 \pm 15$ & $657 \pm 17$ & $3,800 \pm 98$ \\
\hline
\end{tabular}

Duplicate samples of $5 \times 10^{6} \mathrm{U} 1$ cells were labeled in the presence of $\left[{ }^{3} \mathrm{H}\right]$-Dex (total binding) or $\left[{ }^{3} \mathrm{H}\right]$-Dex plus an excess of unlabeled steroid (nonspecific binding). Specific binding to GC receptors was determined by subtracting the nonspecific binding value from that of the total binding, whereas the number of receptors per cell ( \pm S.E.M.) was determined from the specific activity of the labeled Dex. 


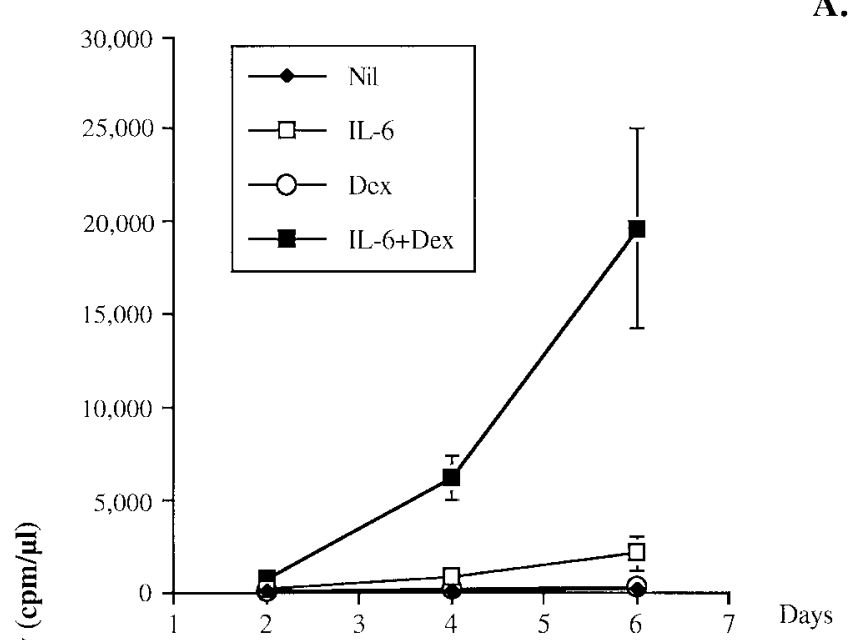

B.

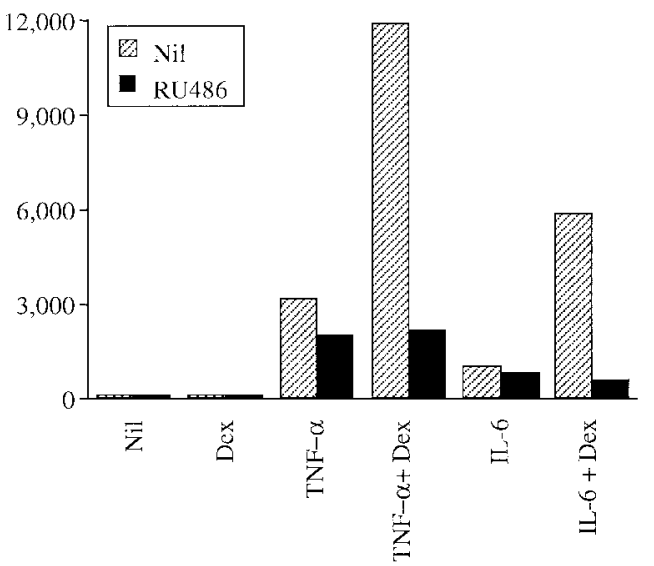

Fig. 1. Synergistic induction of HIV expression by IL-6 and Dex in Ul cells. (A) Kinetics of RT activity produced in culture supernatants after an individual stimulation with IL-6, Dex, or co-stimulation with both agents. The results show the mean \pm SD of 10 independent experiments. (B) RU 486 blocks the synergistic induction of HIV expression in Ul cells costimulated with Dex and cytokines. The results represent peak RT activities measured 4 days after treatment, and were confirmed by determinations performed at day 6 . In some experiments, hydrocortisone instead of Dex was used in the same range of concentrations with identical results.

potentiation of IL-6 induced virus production was unlikely accounted for by substantially increased levels of HIV transcription and/or HIV RNA accumulation, at least by Northern blot analysis.

Dex Inhibits IL-6 Mediated Induction of MCP-1 RNA

We have previously reported that IL- 6 stimulation of both uninfected U937 cells and of the U1 cell line induced the CC-chemokine MCP-1, both at the RNA and protein levels (41). Dex stimulation inhibited the accumulation of MCP-1 mRNA induced by IL- 6 in U I cells (Figure 3B), indicating that the lack of synergistic effect with IL-6 on the accumulation of HIV-1

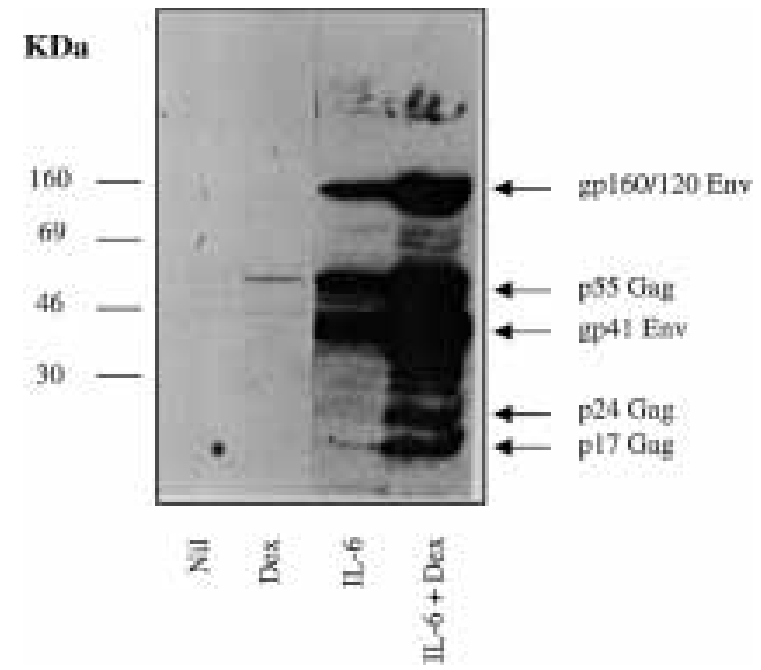

Fig. 2. Western blot analysis of cell-associated HIV-1 proteins. Lysates were prepared from UI cells either unstimulated or stimulated for $48 \mathrm{~h}$ with Dex $\left(10^{-8} \mathrm{M}\right)$, IL-6 $(100 \mathrm{U} / \mathrm{ml})$, or co-stimulated with IL-6 and Dex. The molecular weight markers are indicated on the left and the corresponding major HIV proteins on the right.

transcripts was not a reflection of a generalized refractivity of Ul cells to modulatory effects of GC on gene transcription.

\section{Dex Accelerates AP-1 and ERK1/2 MAPK Activation in U1 Cells Stimulated with IL-6}

In addition to NF-kB dependent transcription, AP-1 activation has been recently shown to mediate cytokine-induced upregulation of virus expression in different cells, including U l cells stimulated with IL6 (48). Therefore, we investigated whether Dex influenced formation of an active AP-1 complex either alone or in the presence of IL-6. Constitutive AP-1 binding was present in nuclear extracts prepared from unstimulated U 1 cells. IL- 6 induced AP- 1 binding in Ul cells after $20 \mathrm{~h}$ of stimulation, as reported (48), but not earlier. Dex alone did not modify the baseline pattern of AP-1 binding, that, however, was enhanced after $8 \mathrm{~h}$ of co-stimulation by IL- 6 plus Dex, indicating that the steroid hormone accelerated IL-6 induced AP- 1 binding (Figure 4A). Ab-mediated supershift analysis of the Ap-1 complex composition induced by IL-6 plus Dex stimulation of U1 cells revealed the presence of JunD, c-Fos, Fra-1 and Fra-2 transcription factors (Fig. 4B). The increased levels of AP- 1 activation observed after $8 \mathrm{~h}$ of co-stimulation by IL- 6 and Dex reflected an analogous pattern of ERK1/2 phosphorylation, that was no longer detectable $20 \mathrm{~h}$ post-stimulation (Fig. 4C).

These results indicate that IL- 6 and Dex can synergize in the induction of certain transcription factors in Ul cells, although this inductive effect does not appear sufficient to increase HIV transcription, as shown in Fig. 3A. 

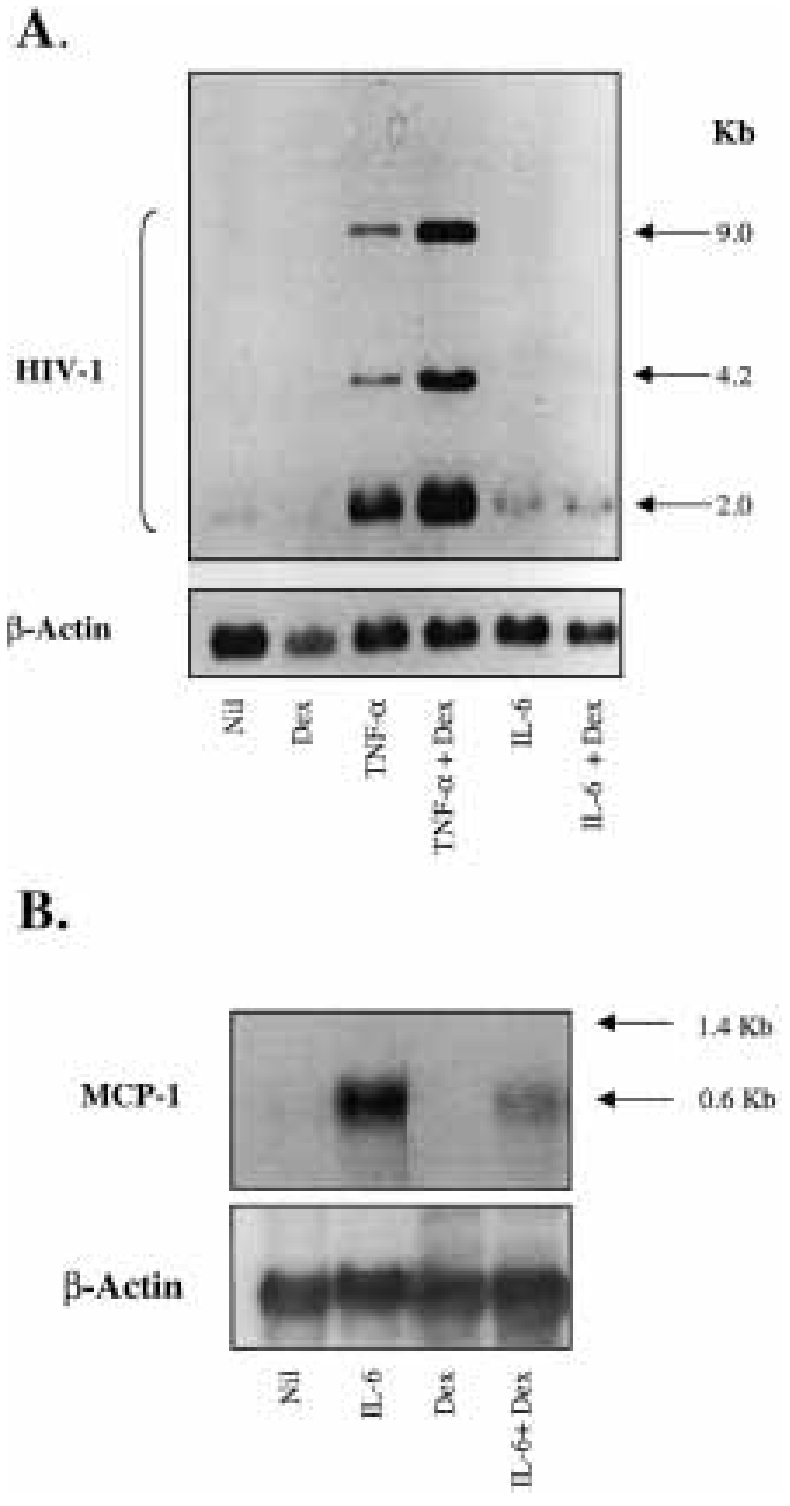

Fig. 3. Northern blot analysis of HIV-1 and MCP-1 RNA. Total RNA was extracted from unstimulated and stimulated $\mathrm{U} 1$ cells after $48 \mathrm{~h}$ of culture for HIV RNA, and after $5 \mathrm{~h}$ of culture for MCP-1. (A) As reported (32), Dex upregulated the expression of HIV RNA in Ul cells following cell incubation with TNF- $\alpha$, whereas it did not alter the low levels of transcripts observed in this cell line either left unstimulated or stimulated with IL-6. (B) IL-6 activates MCP-1 expression in Ul cells (41) and this effect is inhibited by Dex.

\section{IL-6 and Dex Stimulate HIV Expression in U1 and U937 Cells Independently from the Activation of the Virus LTR}

The results obtained thus far suggested that Dex and/or IL-6 did not significantly affect transcription and the steady-state accumulation of viral transcripts above the constitutive levels typical of unstimulated UI cells. UI cells were next transiently transfected with an HIV-1 LTR-CAT plasmid, as described (32), and were either left unstimulated or were stimulated for 4 to $6 \mathrm{~h}$ with Dex, TNF- $\alpha$, IL-6,
A.
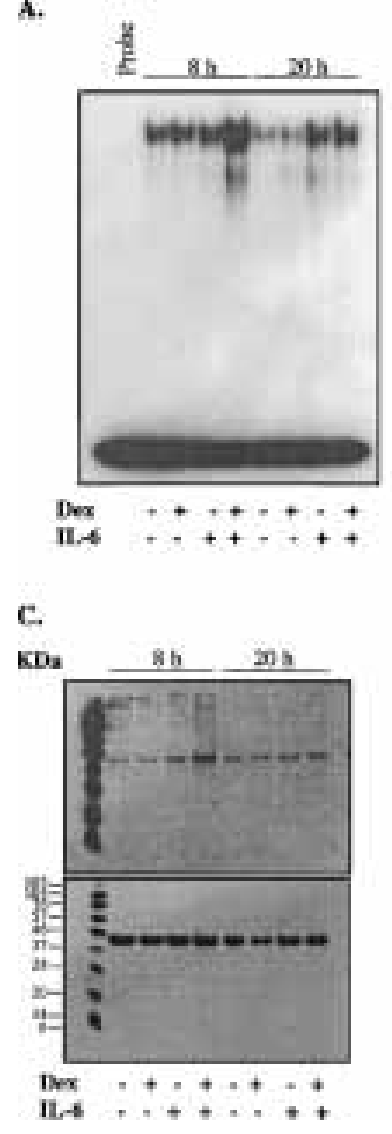

B.

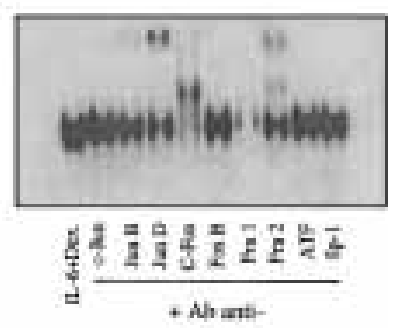

Fig. 4. Dehamethasone increases AP-1 formation and ERK1/2 MAPK phosphorylation in UI cells stimulated with IL-6. (A) Nuclear cell extracts were prepared from U1 cells 8 and $20 \mathrm{~h}$ after stimulation with IL-6, Dex, or the combination of IL-6 and Dex were analyzed for AP-1 activation by EMSA. Dex did not affect the baseline pattern of AP-1 activation, but it potentiated the binding of the transcription factor complex after $8 \mathrm{~h}$, but not after $20 \mathrm{~h}$ of stimulation in the presence of IL-6. (B) Composition of AP-1 in U1 cell nuclear extracts after $8 \mathrm{~h}$ of stimulation with IL-6 plus Dex as analyzed by Ab-mediated supershift analysis. Jun-D, c-Fos, Fra-1 and Fra-2, unlike the other transcription factors examined, were supershifted by their respective Abs; the anti-Spl Ab was used as negative control. (C) ERK 1/2 activation (upper panel) and total amount of ERK 1/2 (bottom panel) were measured in the same nuclear extracts of UI cells analyzed for AP-1 activation. Molecular weight markers are shown on the left side. These results are representative of those obtained in three independent experiments.

or combinations of the individual cytokines and of the steroid hormone. Activation of both the heterologous HIV-LTR plasmid, measured by CAT activity, and of the endogenous proviral DNA, as measured by the production of RT activity, were observed when transfected U1 cells were stimulated with TNF- $\alpha$ (Figure 5A). Of note is the fact that both RT and CAT activities were upregulated by TNF- $\alpha$ at concentrations as low as $1 \mathrm{U} / \mathrm{ml}$, indicating a comparable sensitivity of the two assays in this model system. No effects were observed in terms of either CAT or RT activities in Ul cells stimulated with Dex alone; however, TNF- $\alpha$ induced activation of LTR-driven CAT activity and Dex potentiated this effect (Figure 5B), as previously reported (32). In sharp contrast, negligible activation of CAT activity 

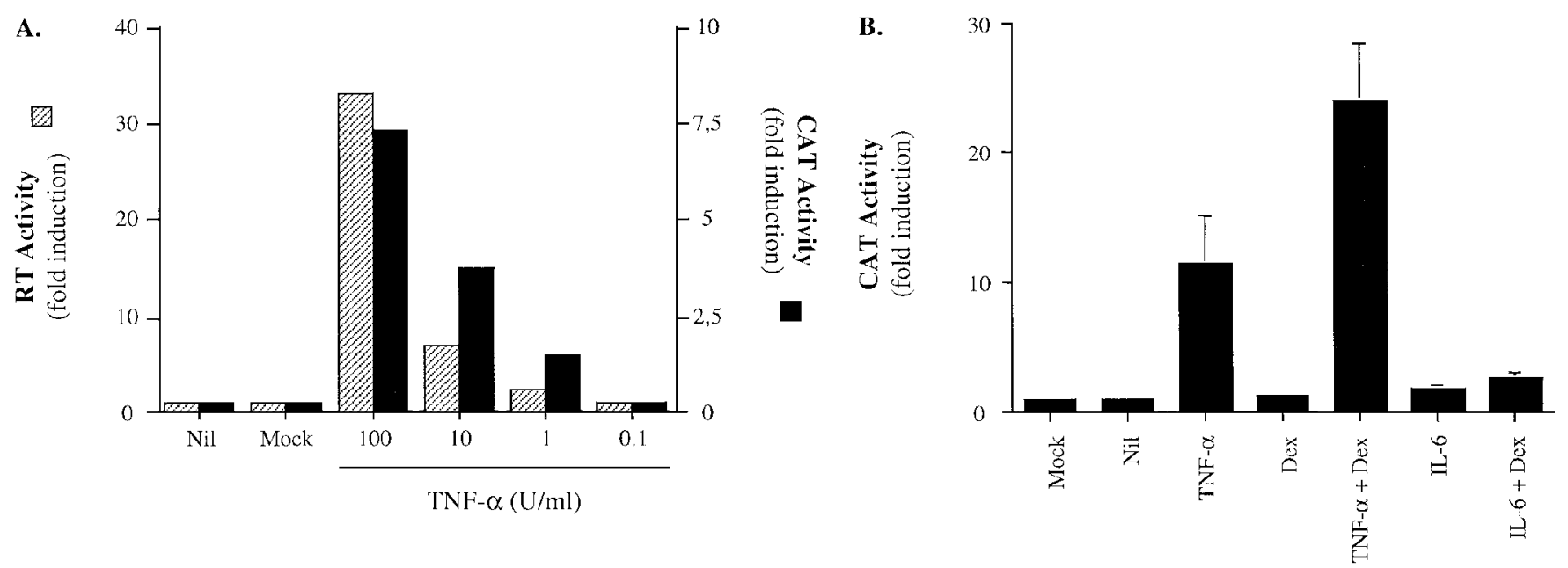

Fig. 5. LTR-independent synergistic induction of HIV expression in Ul cells by IL-6 and Dex. (A) Activation of supernatantassociated RT and CAT activities in U1 cells transiently transfected with an HIV-1 LTR-CAT construct and stimulated with different concentrations of TNF- $\alpha 48 \mathrm{~h}$ after transfection. Although quantitatively different, the sensitivity of Ul cells to the activating effect of TNF- $\alpha$ was comparable in both assays. (B) Lack of HIV LTR activation by stimulation of Ul cells with IL-6, in the presence or absence of Dex. The results represent the mean \pm SD of 4 independent experiments. In no experiments did IL- 6 alone, Dex alone, or their combination induce CAT activity at levels above 2-fold the low constitutive levels observed in unstimulated U1 cells.

was observed when transfected Ul cells were stimulated with IL-6 alone, or with IL-6 plus Dex (Figure 5B). These results strongly suggest that the induction of HIV expression observed in U1 cells costimulated with IL-6 and Dex does not involve the upregulation of LTR-driven transcription. In support of this interpretation, stimulation of Ul cells with IL-6 alone (49) or in the presence of Dex did not activate the cellular transcription factor NF-kB (data not shown).

In order to rule out the possibility that the observed effects were peculiar of Ul cells, uninfected U937 cells were transfected with the HIV-1 LTR-CAT plasmid and then stimulated with either TNF- $\alpha$ or IL- 6 in the presence or absence of Dex. No activation of the virus LTR was observed in U937 cells in the presence of IL- 6 or IL-6 plus Dex in contrast to TNF- $\alpha$ that, either alone or in the presence of Dex, induced CAT activity to an extent comparable to that observed in Ul cells (data not shown).

\section{Discussion}

In the present study, we have demonstrated that a synergistic induction of HIV-1 expression is triggered in chronically infected Ul cells simultaneously stimulated with IL- 6 and Dex. Co-stimulation of Ul cells with the two agents potently induced viral protein expression and de novo virion production independently from either HIV LTR activation or evident accumulation of steady-state HIV transcripts (Fig. 6).

GC mediate their biological effects by binding to cytoplasmic receptors followed by translocation of the steroid/receptor complex to the cell nucleus where recognition of specific target sequences occurs $(50,51)$. Transcriptional activation occurs after interaction of the "zinc finger" DNA binding domain of the glucocorticoid receptor to a DNA sequence represented by the perfect palindrome AGAAACAnnnTGTTCT. Since minimal variations of this sequence are present in the enhancers of different genes, a consensus GC response element (GRE) is represented by the sequence GGTACAnnnTGTTCT (52). In addition, GC receptors can interact with several transcription factors including Jun-Fos (AP-1) $(53,54)$ among others (55).

In addition to cellular genes, GC control the transcription of animal retroviruses including murine mammary tumor virus $(50,56)$ and Moloney murine sarcoma virus (57). Concerning HIV, it has been reported that Vpr, an accessory gene inducing cellcycle arrest, can functionally interact with the glucocorticoid receptor resulting in the potentiation of virus replication (58-61) and HIV expression from different chronically infected cell lines, including U1 (62). Since this effect has been linked to the activation of NF-kB (63), it is unlikely that the potentiating effects here described in Ul cells costimulated with IL-6 and Dex could be ascribed to a similar mechanism. In this regard, the HIV-1 genome contains multiple potential GRE throughout its sequence, with the strongest homology likely occurring in the portion of U3 LTR known as "negative regulatory element" at positions 190-204 in the HXB-2 reference sequence (Genbank ascension number K03455). However, deletion analyses have failed to assign a functional role to this portion of DNA (11-13). Indeed, we could not demonstrate an increase of GC receptor mediated transcription of 


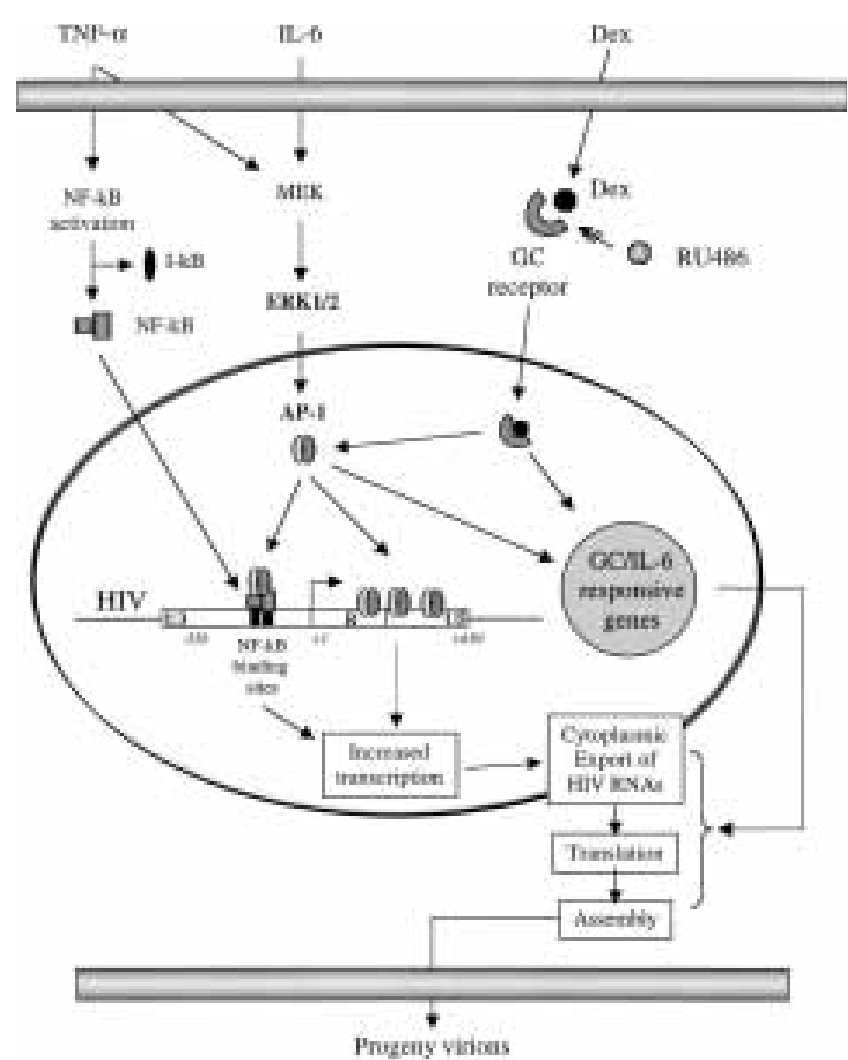

Fig. 6. Model of transcriptional and post-transcriptional synergistic induction of HIV expression in U1 cells by cytokines and GC. IL-6 induces activation of ERK 1/2 MAPK and AP- 1 that can lead to increased viral transcription if Ul cells are simultaneously stimulated with TNF- $\alpha$, a strong inducer of NF$\mathrm{kB}$ activation. Direct binding of AP- 1 complexes to HIV DNA sequences downstream the transcription start site may not always result in increased transcription. Ultimate post-transcriptional synergy can occur in U1 cells co-stimulated by IL-6 and GC as a result of the activation of target cellular and viral genes.

HIV following cell stimulation with steroids by nuclear run-on analysis, or, as here presented, in U937 or U1 cells transiently transfected with an HIV LTR CAT plasmid and stimulated with Dex alone or together with IL-6.

GC biological effects are, however, not limited to transcriptional control of target genes, and their capacity to affect protein expression by acting on different post-transcriptional mechanisms has been well documented. Examples include the suppression of globin mRNA translation in Friend leukemia cells undergoing differentiation (64), the inhibition of $\alpha$ l-acid glycoprotein RNA (65), the accumulation of growth hormone RNA (66), and the inhibition of proinflammatory cytokines such as IL- $1 \beta$ and TNF- $\alpha$ synthesis (19-21). The observation here reported that RU486 blocks the ability of GC to synergize with both TNF- $\alpha$ (32) and IL-6 in the induction of HIV expression indicates that GC receptors are involved in mediating both transcriptional and posttranscriptional effects in Ul cells.
GC have been found to exert both transcriptional and post-transcriptional effects on the IL-6 axis in different model systems (67-72). In a previous study, GC was described to increase the number of IL- 6 receptors (27), thus providing a potential explanation for the synergistic effect observed in our study that, however, was not observed in Ul cells. Furthermore, protein-protein interaction between the GC receptor and NF-IL- 6 were reported to affect the levels of rat $\alpha$-glycoprotein expression (29). However, in the present study, no evidence of cross-modulation of either IL-6 or GC receptors after cell stimulation with IL-6 and Dex was obtained by Northern blotting and by direct binding assay for GC.

The precise mechanism of induction of HIV expression by IL-6 and Dex in U1 cells remains undefined. Both agents display the intrinsic capacity to potentiate HIV transcription in both Ul cells and other model systems in the presence of other stimuli such as TNF- $\alpha(32,34)$ or Tat $(48)$. In this regard, it has been recently proposed that several cytokines, including IL-6, can induce AP-1 via activation of ERK1/2 MAPK leading to formation of AP-1 complexes that cooperated with NF-kB in driving viral transcription from the LTR in U1 and U937 cells costimulated by different cytokines (48). In the same study, however, the authors confirmed our original observation that IL-6 stimulation per se does not lead to substantial NF-kB activation or viral transcription in Ul cells, although it potentiated TNF- $\alpha$ induced HIV transcription and virion expression $(34,49)$. An alternative possibility is that increased viral transcription may occur by activation of an intragenic enhancer containing three functional AP-1 binding sites (73-75). In support of this hypothesis, Dex enhanced both ERK $1 / 2$ activation and the formation of AP-1 complexes induced by IL- 6 after $8 \mathrm{~h}$, but not after $20 \mathrm{~h}$ of stimulation. Although GC usually inhibit AP-1 formation as part of their general antiinflammatory mechanism by the so called "AP-1 GC receptor transcriptional cross-talk" $(76,77)$ potentiation has also been reported (78). Furthermore, Dex-mediated enhancement of IL-6 signaling also been reported in Kaposi's sarcoma cells (31). Either the transient nature of the synergy or the composition of the AP-1 complexes, however, were not sufficient to induce evident accumulation of viral transcripts in contrast to what observed with Ul cells co-stimulated with TNF- $\alpha$ and Dex. In this regard, uncoupling of DNA binding from transcriptional enhancement by Ap-1 has been previously documented $(79,80)$. The observation that levels of HIV expression measured by supernatant-associated RT activity, a faithful indicator of virion production (81), comparable to those induced by TNF- $\alpha$ can be achieved without evident changes in terms of cell-associated viral transcripts strongly argues in favor of a predominant post-transcriptional effect triggered by IL- 6 and GC stimulation of Ul cells. In this regard, similar observation of GC-mediated 
effect independent from the enhancer region itself has also been previously reported in CEM-T4 cells stimulated by PMA, TNF- $\alpha$ or Tat (82). Among other potential mechanisms, activation of ERK 1/2 MAPK has been shown to affect HIV-1 infectivity during acute viral replication (83), a mechanism that has been linked to phosphorylation of the vif gene product $(84,85)$.

Our current study implies that even a profound inhibition of HIV-1 gene transcription may not ultimately result in a total impairment of HIV replication as long as cytokines such as IL- 6 and GC are present. Worthy of note, upregulated levels of IL-6 have been reported in HIV-infected individuals (86-88). These findings are also of relevance in consideration of the broad clinical use of GC in AIDS-related disorders (89) where they are utilized as anti-inflammatory agents (90-93).

\section{Acknowledgments}

We thank Anthony S. Fauci for guidance, suggestions and critical reading of the manuscript, and Massimo Crippa for help with the characterization of AP-1. A.L.K. performed this project for the partial fulfillment of the requirements of the Ph. D. program of the Department of Microbiology and Immunology at George Washington University, Washington, D.C. This work was supported in part by grants of the III $^{\circ}$ National Program for Research Against AIDS of the Istituto Superiore di Sanità, Rome, Italy, and by the M.U.R.S.T 1999 grant n. 9906402221_008.

\section{References}

1. Fauci AS. (1996) Host factors and the pathogenesis of HIVinduced disease. Nature 384: 529-534.

2. Poli G. (1999) Laureate ESCI award for excellence in clinical science 1999. Cytokines and the human immunodeficiency virus: from bench to bedside. European Society for Clinical Investigation. Eur. J. Clin. Invest. 29: 723-732.

3. Da Silva JA. (1999) Sex hormones and glucocorticoids: interactions with the immune system. Ann. N. Y. Acad. Sci. 876: 102-117; discussion 117-118.

4. Clerici M, Bevilacqua M, Vago T, et al. (1994) An immunoendocrinological hypothesis of HIV infection [see comments]. Lancet 343: 1552-1553.

5. Abbott M, Khoo SH., Hammer MR, Wilkins EG. (1995) Prevalence of cortisol deficiency in late HIV disease. J. Infect. 31: 1-4.

6. Biglino A, Limone P, Forno B, et al. (1995) Altered adrenocorticotropin and cortisol response to corticotropin-releasing hormone in HIV-1 infection. Eur. J. Endocrinol. 133: 173-179.

7. Lo JC, Mulligan K, Tai VW, Algren H, Schambelan M. (1998) "Buffalo hump" in men with HIV-1 infection. Lancet 351: 867-870.

8. da Silva B, Singer W, Fong IW, Ottaway CA. (1999) In vivo cytokine and neuroendocrine responses to endotoxin in human immunodeficiency virus-infected subjects. J. Infect. Dis. 180: $106-115$.

9. Markham PD, Salahuddin SZ, Popovic M, et al. (1985) Advances in the isolation of HTLV-III from patients with AIDS and AIDS-related complex and from donors at risk. Cancer Res. 45: 4588s-4591s.
10. Markham PD, Salahuddin SZ, Veren K, et al. (1986) Hydrocortisone and some other hormones enhance the expression of HTLV-III. Int. J. Cancer 37: 67-72.

11. Furth PA, Westphal H, Hennighausen L. (1990) Expression from the HIV-LTR is stimulated by glucocorticoids and pregnancy. AIDS Res. Hum. Retroviruses 6: 553-560.

12. Ghosh D. (1992) Glucocorticoid receptor-binding site in the human immunodeficiency virus long terminal repeat. J. Virol. 66: $586-590$.

13. Soudeyns H, Geleziunas R, Shyamala G, et al. (1993) Identification of a novel glucocorticoid response element within the genome of the human immunodeficiency virus type 1. Virology 194: $758-768$.

14. Mitra D, Sikder SK, Laurence J. (1995) Role of glucocorticoid receptor binding sites in the human immunodeficiency virus type 1 long terminal repeat in steroid-mediated suppression of HIV gene expression. Virology 214: 512-521.

15. Laurence J, Sellers MB, Sikder SK. (1989) Effect of glucocorticoids on chronic human immunodeficiency virus (HIV) infection and HIV promoter-mediated transcription. Blood 74: 291297.

16. Laurence J, Cooke H, Sikder SK. (1990) Effect of tamoxifen on regulation of viral replication and human immunodeficiency virus (HIV) long terminal repeat-directed transcription in cells chronically infected with HIV-1. Blood 75: 696- 703.

17. Swanson B, Zeller JM, Spear GT. (1998) Cortisol upregulates HIV p24 antigen production in cultured human monocytederived macrophages. J. Assoc Nurses AIDS Care 9: 78-83.

18. Penton-Rol G, Cota M, Polentarutti N, et al. (1999) Upregulation of CCR2 chemokine receptor expression and increased susceptibility to the multitropic HIV strain 89.6 in monocytes exposed to glucocorticoid hormones [In Process Citation]. J. Immunol. 163: 3524-3529.

19. Beutler B, Krochin N, Milsark IW, et al. (1986) Control of cachectin (tumor necrosis factor) synthesis: mechanisms of endotoxin resistance. Science 232: 977-980.

20. Knudsen PJ, Dinarello CA, Strom TB. (1987) Glucocorticoids inhibit transcriptional and post-transcriptional expression of interleukin 1 in U937 cells. J Immunol. 139: 4129-4134.

21. Lee SW, Tsou AP, Chan H, et al. (1988) Glucocorticoids selectively inhibit the transcription of the interleukin 1 beta gene and decrease the stability of interleukin 1 beta mRNA. Proc. Natl Acad. Sci. USA 85: 1204-1208.

22. Wingett D, Forcier K Nielson CP. (1996) Glucocorticoidmediated inhibition of RANTES expression in human T lymphocytes. FEBS Lett. 398: 308-311.

23. Chaudhary LR, Avioli LV (1996) Regulation of interleukin-8 gene expression by interleukin-lbeta, osteotropic hormones, and protein kinase inhibitors in normal human bone marrow stromal cells. J. Biol. Chem. 271: 16591-16596.

24. Kelly RW, Carr GG, Riley SC. (1997) The inhibition of synthesis of a beta-chemokine, monocyte chemotactic protein-1 (MCP-1) by progesterone. Biochem. Biophys. Res. Commun. 239: 557-561.

25. Wada T, Furuichi K, Segawa-Takaeda C, et al. (1999) MIPlalpha and MCP-1 contribute to crescents and interstitial lesions in human crescentic glomerulonephritis. Kidney Int. 56: 995-1003.

26. Emilie D, Crevon MC, Auffredou MT, Galanaud P. (1988) Glucocorticosteroid-dependent synergy between interleukin 1 and interleukin 6 for human B lymphocyte differentiation. Eur. J. Immunol. 18: 2043-2047.

27. Snyers L, De Wit L, Content J. (1990) Glucocorticoid upregulation of high-affinity interleukin 6 receptors on human epithelial cells. Proc. Natl. Acad. Sci. USA 87: 2838-2842.

28. Wu CY, Sarfati M, Heusser C, et al. (1991) Glucocorticoids increase the synthesis of immunoglobulin $\mathrm{E}$ by interleukin 4-stimulated human lymphocytes. J. Clin. Invest. 87: 870-877.

29. Nishio Y, Isshiki H, Kishimoto T, Akira S. (1993) A nuclear factor for interleukin-6 expression (NF-IL6) and the glucocorticoid receptor synergistically activate transcription of the rat alpha 1 -acid glycoprotein gene via direct protein-protein interaction. Mol. Cell. Biol. 13: 1854-1862. 
30. Guida L, O'Hehir RE, Hawrylowicz CM. (1994) Synergy between dexamethasone and interleukin-5 for the induction of major histocompatibility complex class II expression by human peripheral blood eosinophils. Blood 84: 27332740.

31. Murakami-Mori K, Mori S, Taga T, et al. (1997) Enhancement of gp 130-mediated tyrosine phosphorylation of STAT3 and its DNA-binding activity in dexamethasone-treated AIDSassociated Kaposi's sarcoma cells: selective synergy between dexamethasone and gp 130-related growth factors in Kaposi's sarcoma cell proliferation. J. Immunol. 158: 5518-5526.

32. Bressler P, Poli G, Justement JS, et al. (1993) Glucocorticoids synergize with tumor necrosis factor alpha in the induction of HIV expression from a chronically infected promonocytic cell line. AIDS Res. Hum. Retroviruses 9: 547-551.

33. Siebenlist U, Franzoso G, Brown K. (1994) Structure, regulation and function of NF-kB. Ann. Rev. Cell Biol. 10: 405-455.

34. Poli G, Bressler P, Kinter A, et al. (1990) Interleukin 6 induces human immunodeficiency virus expression in infected monocytic cells alone and in synergy with tumor necrosis factor alpha by transcriptional and post-transcriptional mechanisms. J. Exp. Med. 172: 151-158.

35. Folks TM, Justement J, Kinter A, et al. (1987) Cytokineinduced expression of HIV-1 in a chronically infected promonocyte cell line. Science 238: 800-802.

36. Folks TM, Justement J, Kinter A, et al. (1988) Characterization of a promonocyte clone chronically infected with HIV and inducible by 13-phorbol-12-myristate acetate. J. Immunol. 140: $1117-1122$.

37. Pomerantz RJ, Trono D, Feinberg MB, Baltimore D. (1990) Cells nonproductively infected with HIV-1 exhibit an aberrant pattern of viral RNA expression: a molecular model for latency. Cell 61: 1271-1276.

38. Poli G, Kinter AL, Justement JS, et al. (1993) The chronically infected cell line U1: a model of HIV expression regulated by cytokines. ImmunoMethods 3: 50-55.

39. Groyer A, Schweizer-Groyer G, Cadepond F, et al. (1987) Antiglucocorticosteroid effects suggest why steroid hormone is required for receptors to bind DNA in vivo but not in vitro. Nature 328: 624-626.

40. Simons SS Jr., Miller PA. (1984) Comparison of DNA binding properties of activated, covalent and noncovalent glucocorticoid receptor-steroid complexes from HTC cells. Biochemistry 23: 6876-6882.

41. Biswas P, Delfanti F, Bernasconi S, et al. (1998) Interleukin-6 induces monocyte chemotactic protein-1 in peripheral blood mononuclear cells and in the U937 cell line. Blood 91: 258265.

42. Cannon P, Kim SH, Ulich C, Kim S. (1994) Analysis of Tat function in human immunodeficiency virus type 1-infected low-level-expression cell lines UI and ACH-2. J. Virol. 68: 1993-1997.

43. Emiliani S, Van Lint C, Fischle W, et al. (1996) A point mutation in the HIV-1 Tat responsive element is associated with postintegration latency. Proc. Natl. Acad. Sci. USA 93: 6377-6381.

44. Emiliani S, Fischle W, Ott M, et al. (1998) Mutations in the tat gene are responsible for human immunodeficiency virus type 1 postintegration latency in the U1 cell line. J. Virol. 72: 1666-1670.

45. Pomerantz RJ, Feinberg MB, Trono D, Baltimore D. (1990) Lipopolysaccharide is a potent monocyte/macrophage-specific stimulator of human immunodeficiency virus type 1 expression. J. Exp. Med. 172: 253-261.

46. Goletti D, Weissman D, Jackson RW, et al. (1996) Effect of Mycobacterium tuberculosis on HIV replication. Role of immune activation. J. Immunol. 157: 1271-1278.

47. Rose-John S, Schooltink H, Lenz D, et al. (1990) Studies on the structure and regulation of the human hepatic interleukin-6 receptor. Eur. J. Biochem. 190: 79-83.

48. Yang X, Chen Y, Gabuzda D. (1999) ERK MAP kinase links cytokine signals to activation of latent HIV-1 infection by stimulating a cooperative interaction of AP-1 and NF-kappaB. J. Biol. Chem. 274: 27981-27988.
49. Poli G, Kinter AL, Fauci AS. (1994) Interleukin 1 induces expression of the human immunodeficiency virus alone and in synergy with interleukin 6 in chronically infected U1 cells: inhibition of inductive effects by the interleukin 1 receptor antagonist. Proc. Natl. Acad. Sci. USA 91: 108-112.

50. Yamamoto KR. (1985) Steroid receptor regulated transcription of specific genes and gene networks. Ann. Rev. Genet. 19: 209-252.

51. Westin S, Rosenfeld MG, Glass CK. (2000) Nuclear receptor coactivators. Adv. Pharmacol. 47: 89-112.

52. Beato M. (1989) Gene regulation by steroid hormones. Cell 56: 335-344.

53. Schule R, Rangarajan P, Kliewer S, et al. (1990) Functional antagonism between oncoprotein c-Jun and the glucocorticoid receptor. Cell 62: 1217-1226.

54. Yang-Yen HF, Chambard JC, Sun YL, et al. (1990) Transcriptional interference between c-Jun and the glucocorticoid receptor: mutual inhibition of DNA binding due to direct protein- protein interaction. Cell 62: 1205-1215.

55. Tasset D, Tora L, Fromental C, et al. (1990) Distinct classes of transcriptional activating domains function by different mechanisms. Cell 62: 1177-1187.

56. Goodman LJ, Firestone GL. (1993) Glucocorticoid-regulated stability of a constitutively expressed mouse mammary tumor virus glycoprotein. Mol. Endocrinol. 7: 94-103.

57. Miksicek R, Heber A, Schmid W, et al. (1986) Glucocorticoid responsiveness of the transcriptional enhancer of Moloney murine sarcoma virus. Cell 46: 283-290.

58. Ayehunie S, Garcia-Zepeda EA, Hoxie JA, et al. (1997) Human immunodeficiency virus-1 entry into purified blood dendritic cells through CC and CXC chemokine coreceptors. Blood 90: 1379-1386.

59. Ayyavoo V, Mahalingam S, Rafaeli Y, et al. (1997) HIV-1 viral protein $\mathrm{R}(\mathrm{Vpr})$ regulates viral replication and cellular proliferation in T cells and monocytoid cells in vitro. J. Leukoc. Biol. 62: 93-99.

60. Kino T, Gragerov A, Kopp JB, et al. (1999) The HIV-1 virionassociated protein vpr is a coactivator of the human glucocorticoid receptor. J. Exp. Med. 189: 51-62.

61. Refaeli Y, Levy DN, Weiner DB. (1995) The glucocorticoid receptor type II complex is a target of the HIV-1 vpr gene product. Proc. Natl. Acad. Sci. USA 92: 3621-3625.

62. Levy DN, Refaeli Y, MacGregor RR, Weiner DB. (1994) Serum Vpr regulates productive infection and latency of human immunodeficiency virus type 1. Proc. Natl. Acad. Sci. USA 91: 10873-10877.

63. Ayyavoo V, Mahboubi A, Mahalingam S, et al. (1997) HIV-1 Vpr suppresses immune activation and apoptosis through regulation of nuclear factor kappa B [see comments]. Nat. Med. 3: 1117-1123.

64. Papaconstantinou J, Stewart JA, Rabek JP, et al. (1983) Glucocorticoids inhibit the coordinated translation of alpha- and beta-globin mRNAs in Friend erythroleukemia cells. Arch. Biochem. Biophys. 227: 542-551.

65. Vannice JL, Taylor JM, Ringold GM. (1984) Glucocorticoidmediated induction of alpha 1-acid glycoprotein: evidence for hormone-regulated RNA processing. Proc. Natl. Acad. Sci. USA 81: 4241-4245.

66. Strobl JS, van Eys GJ, Thompson EB. (1989) Dexamethasone control of growth hormone mRNA levels in GH3 pituitary cells is cycloheximide-sensitive and primarily posttranscriptional. Mol. Cell. Endocrinol. 66: 71-82.

67. Raynal MC, Liu ZY, Hirano T, et al. (1989) Interleukin 6 induces secretion of IgGl by coordinated transcriptional activation and differential mRNA accumulation. Proc. Natl. Acad. Sci. USA 86: 8024-8028.

68. Sanceau J, Merlin G, Wietzerbin J. (1992) Tumor necrosis factor-alpha and IL-6 up-regulate IFN-gamma receptor gene expression in human monocytic THP-1 cells by transcriptional and post-transcriptional mechanisms. J. Immunol. 149: 1671-1675.

69. Steel DM, Rogers JT, DeBeer MC, et al. (1993) Biosynthesis of human acute-phase serum amyloid A protein (A-SAA) 
in vitro: the roles of mRNA accumulation, poly(A) tail shortening and translational efficiency. Biochem. J. 291: 701707.

70. Sneed TB, Stanley DJ, Young LA, Sanderson RD. (1994) Interleukin-6 regulates expression of the syndecan-1 proteoglycan on B lymphoid cells. Cell. Immunol. 153: 456467.

71. Cohen T, Nahari D, Cerem LW, et al. (1996) Interleukin 6 induces the expression of vascular endothelial growth factor. J. Biol. Chem. 71: 736-741.

72. Hernandez J, Molinero A, Campbell IL, Hidalgo J. (1997) Transgenic expression of interleukin 6 in the central nervous system regulates brain metallothionein-I and -III expression in mice. Brain Res. Mol. Brain Res. 48: 125-131.

73. Verdin E, Becker N, Bex F, et al. (1990) Identification and characterization of an enhancer in the coding region of the genome of human immunodeficiency virus type 1. Proc. Natl. Acad. Sci. USA 87: 4874-4878.

74. Van Lint C, Burny A, Verdin E. (1991) The intragenic enhancer of human immunodeficiency virus type 1 contains functional AP-1 binding sites. J. Virol. 65: 7066-7072.

75. Rabbi MF, Saifuddin M, Gu DS, et al. (1997) U5 region of the human immunodeficiency virus type 1 long terminal repeat contains TRE-like cAMP-responsive elements that bind both AP-1 and CREB/ATF proteins. Virology 233: 235245.

76. Gottlicher M, Heck S, Herrlich P. (1998) Transcriptional cross-talk, the second mode of steroid hormone receptor action. J. Mol. Med. 76: 480-489.

77. Karin M, Chang L. (2001) AP-1-glucocorticoid receptor crosstalk taken to a higher level. J. Endocrinol. 169: 447451.

78. Miyazaki Y, Yokozeki H, Awad S, et al. (2000) Glucocorticoids augment the chemically induced production and gene expression of interleukin-lalpha through NF-kappaB and AP-1 activation in murine epidermal cells. J. Invest. Dermatol. 115: 746-752.

79. Karin, M. (1995) The regulation of AP-1 activity by mitogenactivated protein kinases. J. Biol. Chem. 270: 16483-16486.

80. Leppa S, Saffrich R, Ansorge W, Bohmann D. (1998) Differential regulation of c-Jun by ERK and JNK during PC12 cell differentiation. Embo. J. 17: 4404-4413.
81. Fernie BF, Poli G, Fauci AS. (1991) Alpha interferon suppresses virion but not soluble human immunodeficiency virus ntigen production in chronically infected T-lymphocytic cells. J. Virol. 65: 3968-3971.

82. Russo FO, Patel PC, Ventura AM, Pereira CA. (1999) HIV-1 long terminal repeat modulation by glucocorticoids in monocytic and lymphocytic cell lines. Virus. Res. 64: 87-94.

83. Cartier C, Deckert M, Grangeasse C, et al. (1997) Association of ERK2 mitogen-activated protein kinase with human immunodeficiency virus particles. J. Virol. 71: 4832-4837.

84. Jacque JM, Mann A, Enslen H, et al. (1998) Modulation of HIV-1 infectivity by MAPK, a virion-associated kinase. Embo. J. 17: 2607-2618.

85. Yang X, Gabuzda D. (1999) Regulation of human immunodeficiency virus type 1 infectivity by the ERK mitogenactivated protein kinase signaling pathway. J. Virol. 73: 34603466.

86. Gallo P, Frei K, Rordorf C, et al. (1989) Human immunodeficiency virus type 1 (HIV-1) infection of the central nervous system: an evaluation of cytokines in cerebrospinal fluid. $J$. Neuroimmunol. 23: 109-116.

87. Breen EC, Rezai AR, Nakajima K. (1990) Infection with HIV is associated with elevated IL-6 levels and production. $J$. Immunol. 144: 480-484.

88. Laverda AM, Gallo P, De Rossi A, et al. (1994) Cerebrospinal fluid analysis in HIV-1-infected children: immunological and virological findings before and after AZT therapy. Acta. Paediatr. 83: 1038-1042.

89. Limoges J, Persidsky Y, Bock P, Gendelman HE. (1997) Dexamethasone therapy worsens the neuropathology of human immunodeficiency virus type 1 encephalitis in SCID mice. J. Infect. Dis. 175: 1368-1381.

90. Masur H. (1992) Prophylaxis and therapy for Pneumocystis pneumonia-where are we? Infect. Agents Dis. 1: 270-278.

91. Schliep TC, Yarrish RL. (1999) Pneumocystis carinii pneumonia. Semin. Respir. Infect. 14: 333-343.

92. Bainbridge JW, Raina J, Shah SM, et al. (1999) Ocular complications of intravenous cidofovir for cytomegalovirus retinitis in patients with AIDS. Eye 13: 353-356.

93. Lauerma AI, Jeskanen L, Rantanen T, et al. (1999) Cryptococcosis during systemic glucocorticosteroid treatment. Determatology 199: 180-182. 